\title{
Richness and structure of ant assemblies (Hymenoptera: Formicidae) in Atlantic forest in southern Brazil
}

\author{
JUNIR A. LUTINSKI ${ }^{1}$, CLADIS J. LUTINSKI ${ }^{2}$, CARIN GUARDA ${ }^{1}$, \\ MARIA A. BUSATO ${ }^{1}$ and FLÁVIO R.M. GARCIA ${ }^{3}$ \\ ${ }^{1}$ Programa de Pós-Graduação em Ciências da Saúde, Universidade Comunitária da Região de Chapecó/ \\ UNOCHAPECÓ, Av. Senador Attílio Fontana, 591-E, Efapi, Caixa Postal 1141, 89809-000 Chapecó, SC, Brazil \\ ${ }^{2}$ Departamento de Biologia, Universidade Federal da Fronteira Sul/UFFS, Av. \\ Fernando Machado, 108 E, 89802-112 Chapecó, SC, Brazil \\ ${ }^{3}$ Programa de Pós-Graduação em Entomologia, Universidade Federal de Pelotas/UFPel, \\ Instituto de Biologia, Porto, Caixa Postal 354, 96010-900 Pelotas, RS, Brazil
}

Manuscript received on December 22, 2016; accepted for publication on August 14, 2017

\begin{abstract}
Ant diversity is influenced by the structural complexity of the environment. Ants are thus an ecologically important group due to their potential to serve as indicators of environmental quality. The objective of this study was to evaluate ant diversity in areas with different land use histories and thus, within different stages of regeneration in the Permanent Preservation Area of the Foz do Chapecó Hydroelectric Plant reservoir. Ant assemblies among sample sites were compared using rarefaction analysis, and estimated richness, frequency of occurrence, and relative abundance were calculated. Associations between species and sample sites were evaluated using Principal Component Analysis (PCA). We identified 55 species in total from 24 genera, distributed among seven subfamilies. Eight species had positive associations with sample sites. Estimates indicated that ant richness may be up to $21.4 \%$ greater than that observed. This study presents an inventory of species capable of colonizing environments undergoing natural regeneration processes, and aids our understanding of ecological recovery dynamics in protected areas near hydroelectric plant reservoirs southern Brazil.
\end{abstract}

Key words: ant fauna, hydroelectric plant, Permanent Preservation Areas, richness, ants.

\section{INTRODUCTION}

Brazil is among the locations with the highest global biological diversity. It boasts a unique natural heritage expressed through various endemic biomes (Marques and Lamas 2006), including the Brazilian Atlantic forest (Galindo-Leal and

Correspondence to: Junir Antonio Lutinski

E-mail: junir@unochapeco.edu.br
Câmara 2003). Anthropogenic activities such as conversion of natural environments for agricultural purposes, raising of livestock, industrial facilities, and energy production, and urbanization generate environmental impacts that lead to biodiversity losses (Madeira et al. 2009, Gardner 2010, Diamond 2012) and represent one of the important threats to the remnants of the Atlantic Forest (Galindo-Leal and Câmara 2003). 
Forty-eight hydroelectric plants (HPs) and 146 small hydroelectric plants (SHPs) are currently in operation across the southern region of Brazil (Aneel 2016). Hydroelectric dams represent a lower impact alternative in the energy matrix compared to fossil fuel power plants (Kliemann and Dalariva 2015). However, the construction of dams necessarily suppresses vegetation and displaces species, causing soil turnover and compaction, culminating with the formation of the lake (Barbosa Filho 2013, Kliemann and Dalariva 2015). These environmental alterations translate into habitat loss, species displacement, local microclimatic changes, and a restructuring of the ecosystem adjacent to the lake formation. These adjacent ecosystems are thus protected and designated as Permanent Preservation Areas (PPAs) in accordance with the Brazilian forest code (Brazil 2012).

PPAs play an important role in river basin management, as protection of these areas contributes to the stability of hydrological and biogeochemical cycles as well as the maintenance of ecological equilibrium (Tundisi and Tundisi 2010). PPAs are considered to be determinants of biodiversity conservation (Bensusan 2006), and together with the remaining forest fragments, they ensure favorable conditions for the establishment and maintenance of flora and fauna (Gibson et al. 2011, Ulyshen 2011). Considering the growing number of hydroelectric plants in the southern region in the last two decades and the ongoing fragmentation of Atlantic forest (i.e., a biome with high endemism), there is a strong need to understand regeneration dynamics in PPAs adjacent to hydroelectric dams and the potential of these areas for conservation of biodiversity.

Ants (Hymenoptera: Formicidae) comprise a highly functional and specialized taxon (Hölldobler and Wilson 1990, Petters et al. 2011) and are an important component of terrestrial ecosystems, constituting a large part of total animal biomass (Nayana et al. 2016). They are reliable indicators of ecological change (Andersen and Majer 2004) and conservation status (Majer 1983, Andersen 1997, King et al. 1998, Silva and Brandão 1999, Alonso 2000, Ilha et al. 2009). They have potential to serve as bioindicators due to intimate associations with plant flora, providing estimation of the degree of environmental preservation (Lutinski et al. 2014, 2016) and habitat structural complexity (Fowler et al. 1991, Perfecto and Vandermeer 2002, Armbrecht et al. 2004). Ant communities are affected by vegetation regeneration processes (Ribas et al. 2012), where the intensity of environmental degradation or alteration can produce various responses, benefitting some species and harming others (Hölldobler and Wilson 1990).

Ant biodiversity is significant in terrestrial ecosystems (Hölldobler and Wilson 1990), and is sensitive to anthropogenic impacts and associated biotic and abiotic factors, which can determine species richness and influence species distributions (Pereira et al. 2007, Lutinski et al. 2014, Nayana et al. 2016). Ants are useful for assessing the animal biodiversity responses to forest restoration (Neves et al. 2010, Wetterer 2012), and PPAs may serve are important tools for assessing the process of environmental restoration and the rebuilding of biological communities.

Although the ant fauna of the southern Atlantic forest biome is well described (Silva and Silvestre 2004, Lutinski et al. 2008, 2014, Maciel et al. 2011, Ulysséa et al. 2011), studies of ants associated with PPAs near hydroelectric dams are still needed, particularly concerning the potential role of these insects as bioindicators in the postconstruction period. Previous studies in this region found rich ant assemblages in a diverse array of environments (Lutinski and Garcia 2005, Iop et al. 2009, Lutinski et al. 2008). The Foz de Chapecó is one of the largest HPPs in southern Brazil, and evaluation of ant communities in the adjacent PPA may inform our understanding of species richness and distributions over large areas of Santa Catarina 
and Rio Grande do Sul, serving as a basis for subsequent studies. A better understanding of ant species richness and composition in this area is also essential for PPA management and consolidation, and may provide additional information to bolster conservation plans.

The objective of this study was a) to characterize ant assemblies in the Foz do Chapecó hydroelectric dam PPA, characterizing species richness, abundance, and composition; and b) to evaluate species richness and associations of PPA environments with different land use histories prior to lake formation.

\section{MATERIALS AND METHODS}

\section{STUDY AREA}

The field work was conducted in January 2016 in the permanent preservation area (PPA) of the Foz do Chapecó hydroelectric dam reservoir, a border area between the states of Santa Catarina and Rio Grande do Sul. The region is part of the Atlantic forest biome (Mixed Ombrophilous forest), and the climate is subtropical super-humid mesothermic, with no defined dry season, frequent frosts, and even distribution of rainfall throughout the year (Inmet 2009).

The Foz do Chapecó hydroelectric power plants (HPP) reservoir has an area of $79.2 \mathrm{~km}^{2}$ and an installed capacity of $855 \mathrm{mw}$. The area extends to the municipalities of Águas de Chapecó, Caxambú do Sul, Guatambu, Chapecó, Paial, and Itá in Santa Catarina, and Rio dos Índios, Nonoai, Faxinalzinho, Erval Grande, and Itatiba do Sul in Rio Grande do Sul (Foz do Chapecó 2015). The reservoir was formed in 2010, and sampling of the PPA took place five years later. Ants were collected in four sites with an area of two hectares each. Two sites were sampled in Santa Catarina: Guatambu (2714'59" S, 52 41'06" W) and Caxambu do Sul (27 $\left.15^{\circ} 35^{\prime \prime} \mathrm{S}, 52^{\circ} 42^{\prime} 40^{\prime \prime} \mathrm{W}\right)$; and two sites were sampled in Rio Grande do Sul, both in the Rio dos
Índios municipality $\left(27^{\circ} 17^{\prime} 38^{\prime \prime} \mathrm{S}, 52^{\circ} 44^{\prime} 58^{\prime \prime} \mathrm{W}\right.$ and $\left.27^{\circ} 20^{\prime} 41^{\prime \prime} \mathrm{S}, 52^{\circ} 43^{\prime} 51^{\prime \prime} \mathrm{W}\right)$.

The first site in Guatambu (GUA) consists of eucalyptus plantation (Eucalyptus spp.) aged approximately 10 years. At the time of hydroelectric dam lake formation, vegetation in the PPA was not suppressed. A sub-forest is currently forming, composed of native vegetation and with a height of up to five meters. The area has no observed litter formation, and is segmented by several trails that are used by fishermen and tourists. The second site in Caxambu do Sul (CXS) includes an agricultural (crop) area that was isolated with wire fence and allowed to regenerate after lake formation. The native vegetation is composed mostly of sparse grasses and shrubs up to five meters in height. The area is divided by an old road providing access to lake vacationers. The third site in Rio dos Índios (RI1) is pasture area that, like site two, was isolated and allowed to regenerate. The environment currently consists of sparse adult trees that existed before lake formation, as well as grasses and small shrubs. The forth site, also in Rio dos Índios (RI2), is in advanced stages of regeneration, and is covered by dense vegetation approximately 20 years in age. The ground has well-formed litter cover, and the forest fragment was included in the PPA after formation of the reservoir.

\section{ANT COLLECTION}

Three, $100 \mathrm{~m}$ linear transects were established in each sample site for ant collection. Pitfall traps were established along one transect, consisting of $250 \mathrm{ml}$ plastic cups (10 cm diam. x $12 \mathrm{~cm}$ height) buried in the soil with the opening at ground level, with a distance of $10 \mathrm{~m}$ between traps. The traps contained $150 \mathrm{ml}$ of water and one drop of detergent to break surface tension. The second transect contained sardine bait $(\sim 1 \mathrm{~g})$, and the third transect contained glucose bait $(\sim 1 \mathrm{~mL})$. Baits were arranged on 20 $\times 30 \mathrm{~cm}$ paper rectangles and placed on the ground 
$10 \mathrm{~m}$ apart. Pitfalls remained in the field for 48 hours prior to collection, while baits remained in the field for one hour (Lutinski et al. 2013).

Specimens were stored in bottles containing $70 \%$ ethanol and transported to the Entomology Laboratory at the Universidade Comunitária da Região de Chapecó (Unochapecó) for sorting and identification.

\section{SPECIES IDENTIFICATION}

Ant species identification was based on taxonomic keys by Gonçalves (1961), Kempf (1964, 1965), Watkins (1976), Della Lucia (1993), Lattke (1995), Taber (1998), Fernández (2003), Longino (2003), Wilson (2003), Longino and Fernández (2007), and Wild (2007). Specimens were also compared with those deposited in the Entomological Collection at Unochapecó. Classification was based on Bolton (2003), and nomenclature was validated using the website antbase.org on November 2, 2016.

\section{DATA ANALYSIS}

Richness was defined as the number of species in a single sample. Frequency of occurrence (capture) per sample site was used as a proxy for abundance. This method minimizes the effects of differences in foraging habits and colony size, and is thus more appropriate for studies of ant assemblages (Romero and Jaffe 1989). Richness for each ant assemblage was compared by rarefaction analyses without occurrence data (Gotelli and Colwell 2001). Analyses were carried out in EcoSim 7 (Gotelli and Entsminger 2001), which allows richness comparisons among ant assemblages that differ in species occurrence (Melo et al. 2003).

We also obtained a general estimate of richness for the hydroelectric dam PPA, and compared this value with observed richness using a nonparametric estimator (Chao 1) in EstimatesS 8.0 (Colwell 2006). This estimator essentially uses information about species that only occur in one sample (unicates) and those that occur in two samples (duplicates) (Chao 1987).

We ran a Principal Component Analysis (PCA) in the Past statistical program (Hammer et al. 2001) to test for associations between ant species and environment (site). Thirty species were excluded from the PCA due to low occurrence $(\leq 2)$. The data were $\log (\mathrm{x}+1)$ transformed prior to analyses.

The study was authorized by the Chico Mendes Institute for Conservation of Biodiversity (ICMBio) by issue of an "authorization for scientific activities" permit ( $\left.{ }^{\circ} 50739-1 ; 11 / 30 / 2015\right)$.

\section{RESULTS}

We collected 313 ants in total, including 55 species across 24 genera and seven subfamilies. The GUA site ant assemblage had the highest richness $(S=27)$, followed by RI1 $(S=26)$ and RI2 ( $\mathrm{S}=21)$. Myrmicinae ( $\mathrm{S}=27)$, Formicinae ( $=11)$ and Ponerinae $(\mathrm{S}=6)$ were the subfamilies with the highest richness. The genera with highest species richness were Pheidole $(\mathrm{S}=11)$, Camponotus $(\mathrm{S}=5)$, and Linepithema $(\mathrm{S}=5)$. Only eight species occurred in all sample sites: Camponotus (Myrmothrix) rufipes (Fabricius, 1775), Odontomachus chelifer (Latreille, 1802), Pachycondyla striata F. Smith, 1858, Pheidole pubiventris Mayr, 1887, Pheidole risii Forel, 1892, Pheidole dyctiota Kempf, 1972, Pheidole punctatissima Mayr, 1870, and Solenopsis sp. The GUA ant assemblage had the highest number of exclusive species $(\mathrm{S}=10)$, followed by RI1 ( $\mathrm{S}$ $=9)$, RI2 $(\mathrm{S}=8)$, and CXS $(\mathrm{S}=4)$ (Table SI Supplementary Material).

The Myrmicinae subfamily had the greatest richness, with 27 species in total, 21 in the Rio Grande do Sul sites (RS) and 16 species in the Santa Catarina sites (SC). Formicinae was the secondrichest subfamily with eleven species in total, eight in RS and 10 in SC. The most common species were $P$. dyctiota (GUA: 12\%, CXS: 18\%, RI1: $8 \%$, 
RI2: 8\%), P. rissi (GUA: 23\%, CXS: 15\%, RI1: 3\%, RI2: $20 \%$ ) and P. striata (GUA: 13\%, CXS: 14\%, RI1: 8\%, RI2: 7\%) (Table SI).

The difference between observed richness $\left(\mathrm{S}_{\mathrm{obs}}\right)$ and estimated richness (Chao1) was 21.4\%. There was a tendency towards increased richness from supplementary samples as accumulation curves did not reach asymptote (Figure 1). The GUA, RI1, and RI2 sites did not differ in species richness according the rarefaction analysis, and the CXS site had lower richness than the others (Figure 2). Among the sampled sites, $82.9 \%$ of the variation in ant occurrence was explained by components 1 and 2 from the PCA. Six species showed a positive association with GUA, CXS and RI2: $O$. chelifer, P. striata, $P$. dyctiota, $P$. pubiventris, $P$. risii, and Solenopsis sp. Two species were positively associated with RI1: C. rufipes and Pheidole sp. 1. Other species showed no associations with sample site (Figure 3).

\section{DISCUSSION}

The ant fauna found in this study generally agrees with previous surveys in the region. The 40 species sampled in Santa Catarina sites represent $19.3 \%$ of those described for the western region of the state (Ulysséa et al. 2011). The species sampled in Rio

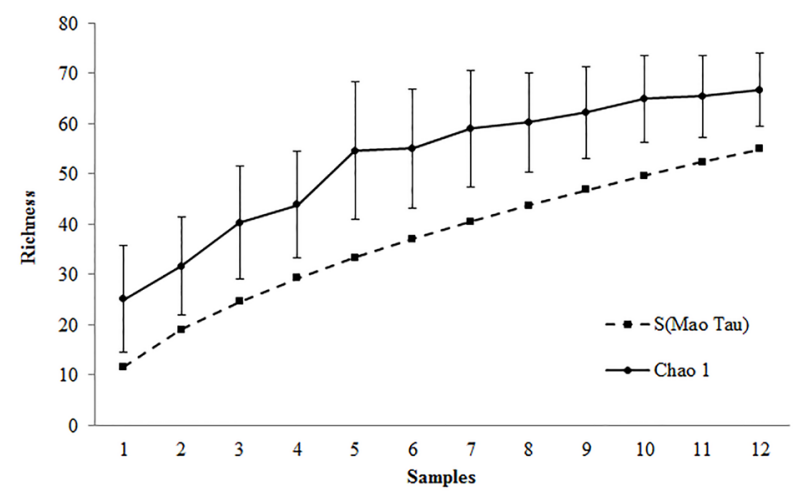

Figure 1 - Observed (S(Mao Tau)) and estimated (Chaol) ant richness in the Permanent Preservation Area in the Foz do Chapecó hydroelectric power plant lake area in Guatambu (GUA) and Caxambu do Sul (CXS) in Santa Catarina, and in Rio de Índios (RI1 and RI2) in Rio Grande do Sul (January 2016). dos Índios represent $32.4 \%$ of ant fauna recorded by Cantarelli et al. (2015) for environments in the northwest region of Rio Grande do Sul. The ant assemblages sampled generally included subfamilies and genera recognized for playing important roles at various trophic levels in the ecosystem (Hölldobler and Wilson 1990), and included taxa that are frequently found in regional studies (Lutinski and Garcia 2005, Lutinski et al. 2008, 2013, Ulysséa et al. 2011, Cantarelli et al. 2015, Fleck et al. 2015). The $21.4 \%$ difference between estimated and observed richness suggests that numbers of ant species found in these environments should increase with additional sampling effort. The eight species showing positive association with at least one of the sample sites were common species that frequently occur in different environments in this region (Ulysséa et al. 2011, Lutinski et al. 2014).

The subfamily Myrmecinae is dominant (i.e., in both genus and species number) in Brazilian biomes such as Atlantic forest and Cerrado. Species in this subfamily have several characteristics that account for their remarkable success, principally broad diversity in feeding and nesting habits (Hölldobler and Wilson 1990). The predominance of Myrmicinae can also be explained by the

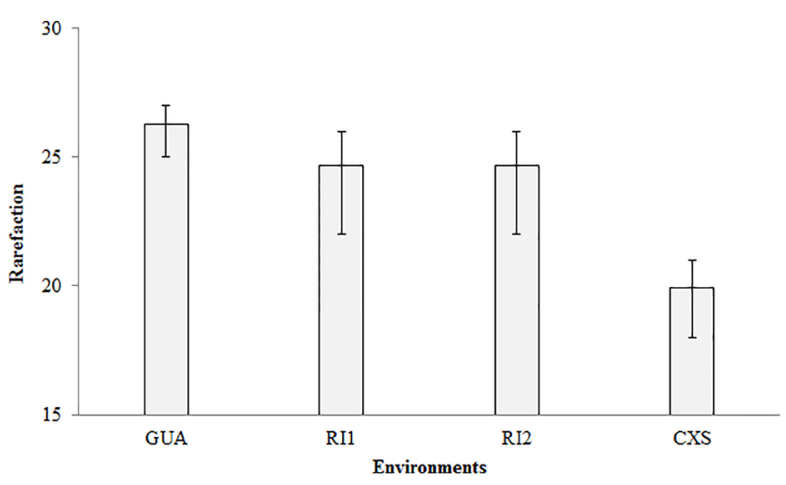

Figure 2 - Rarefaction analyses comparing ant assemblages sampled in four PPA sites (Guatambu (GUA) and Caxambu do Sul (CXS) in Santa Catarina, and Rio dos Índios (RI1 and RI2) in Rio Grande do Sul), in the Foz do Chapecó hydroelectric power plant lake area (January 2016). 


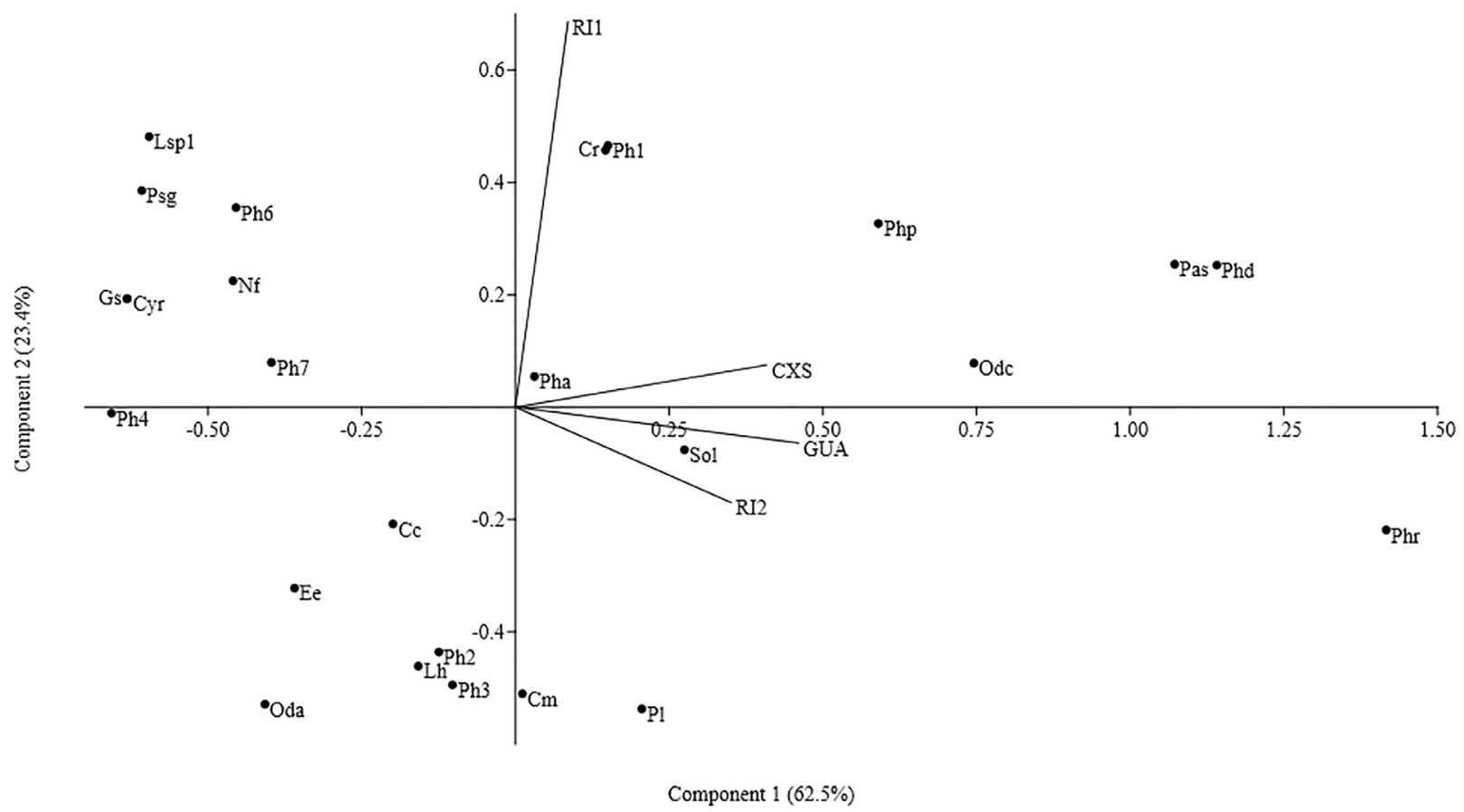

Figure 3 - Principal Component Analysis (PCA) of the ant species at four sites (Guatambu (GUA) and Caxambu do Sul (CXS) in Santa Catarina, and Rio dos Índios (RI1 and RI2) in Rio Grande do Sul). Guatambu (GUA) and Caxambu do Sul (CXS) sites are in Santa Catarina, and both Rio dos Índios sites (RI1 e RI2) are in Rio Grande do Sul. Species abbreviations are as follows: Cc: Camponotus (M.) crassus; Cm: Camponotus (M.) mus; Cr: Camponotus (M.) rufipes; Cyr: Cyphomyrmex rimosus; Ee: Ectatomma edentatum; Gs: Gnamptogenys striatula; Lh: Linepithema humile; Lsp1: Linepithema sp. 1; Nf: Nylanderia fulva; Oda: Odontomachus affinis; Odc: Odontomachus chelifer; Pas: Pachycondyla striata; Ph1: Pheidole sp. 1; Ph2: Pheidole sp. 2; Ph3: Pheidole sp. 3: Ph4: Pheidole sp. 4: Ph6: Pheidole sp. 6: Ph7: Pheidole sp. 7; Pha: Pheidole punctatissima; Phd: Pheidole dyctiota; Php: Pheidole pubiventris; Phr: Pheidole risii; P1: Paratrechina longicornis; Psg: Pseudomyrmex gracilis; Sol: Solenopsis sp.

capacity of this group to adapt to environmental change, and their ability to occupy different niches (Fowler et al. 1991).

Linepithema species are characteristic of anthropogenically altered environments, and frequently occur in diverse environments of southern Brazil (Ulysséa et al. 2011, Lutinski et al. 2014) where they dominate the food resources and have massive recruitment (Silvestre et al. 2003). According to Fernández (2003), some of the most important pest or potential pest species belong to this genus, highlighting L. humile. The omnivorous habits of ants in this group and the occurrence of five species from this genus in the study environment are indicative of initial processes of ecological recovery.

Camponotus was the second-richest genus in the study. Approximately 400 species are described for this genus in the Neotropical region, among which polymorphism and omnivory are commonplace (Makay et al. 2002). These species forage from the ground to the treetops. The use of chemical defense and mutualistic interactions with other organisms are also common occurrences (Silvestre et al. 2003). Camponotus crassus, $C$. mus, and C. rufipes are widely distributed in Santa Catarina (Ulysséa et al. 2011) and frequently occur in anthropogenic environments (Lutinski et al. 2014). The genus Pheidole presented the 
highest richness and, together with Solenopsis are described as epigeal, omnivorous, and dominant (Silvestre et al. 2003). These genera are extremely diverse in Brazil (Baccaro et al. 2015), with dozens of species recorded in single locations. Their wide geographic distribution and strong dispersal capability make some species locally abundant. Silvestre et al. (2003) associate these genera with nesting in the soil and formation of large colonies, having small body size, and being monomorphic or dimorphic with generalist and aggressive behavior. They are often found in anthropogenically altered environments (Lutinski and Garcia 2005, Lutinski et al. 2014). The PPA was only in recovery for five years at the time of the current study, thus local microclimatic changes triggered by the HPP lake formation likely still produced some degree of environmental impact on the flora and fauna; this may partially explain the richness of these dominant ant genera in the PPA sites.

We found two species of leafcutter ants in the genus Acromyrmex. Ants in this genus are regionally abundant (Lutinski et al. 2008, 2013), with nine species occurring in the western region of Santa Catarina (Ulysséa et al. 2011) and ten in Rio Grande do Sul (Loeck et al. 2003). In this study, Acromyrmex did not occur in the Rio Grande do Sul sites. Some of the species with the greatest potential to cause economic damage are in this genus, since they are associated with environmental imbalances that lead to population imbalances, leading to increase in cutting of vegetative mass (Fernández 2003). These are polymorphic ants that are endemic to the Neotropical region. They play an important role in soil maintenance, which they use for nest construction. They construct underground galleries, an action which plays an important role in soil aeration; droppings and decaying vegetable matter enrich the soil, primarily through means of fungal production (Silvestre et al. 2003).

The occurrence of species in the genera Acanthognathus, Apterostigma, Cyphomyrmex,
Dinoponera, Ectatomma, Gnamptogenys, Heteroponera, Hypoponera, Mycocepurus, Neoponera, Pachycondyla, Odontomachus and Strumigenys emphasizes the importance of the PPA regeneration process in the formation of litter, which these ants utilize for shelter and food (Silvestre et al. 2003). Acanthognathus, Dinoponera, Ectatomma, Gnamptogenys, Heteroponera, Hypoponera, Neoponera, Pachycondyla, Odontomachus and Strumigenys are specialized predators that forage in the litter and on the ground. In addition to the predatory habit, ants of these genera share the habit of building their nests in fallen logs, under rocks, or in litter (Lattke 2003). They are identified in the field by having low agility and forming small colonies, as well as by small body size and the presence of a constriction between the first and second gastral segments. They have affinity with shaded and humid environments, and prey indiscriminately upon small invertebrates. Apterostigma, Cyphomyrmex, and Mycocepurus use decaying organic matter for the cultivation of fungi that they use as food (Silvestre et al. 2003).

Among other general characteristics of Brachymyrmex, Crematogaster, Nylanderia, Paratrechina and Wasmannia species (Silvestre et al. 2003, Lutinski et al. 2014), omnivorous habits may explain their occurrence in the sampled environments. Massive recruitment and diminutive size in these species (Oliveira and CamposFarinha 2005, Silvestre et al. 2003) may also favor dominance of food sources and high occurrence in the PPAs.

The Chao1 estimator showed that ant richness in the PPAs may be on average $21.4 \%$ larger than the observed richness. The effort required to sample all the existing specimens in a given environment can be up to 10 times higher than the original effort (Chao et al. 2009), and considering the state of environmental recovery and sampled richness, it is highly likely that subsequent samples will expand species records in the area. The use of additional 
capture methods, as Winkler traps may increase the richness too. The rarefaction analysis results suggest small differences in ant richness among the four sample sites, indicating the existence of similar factors among sites that maintain the PPA ant fauna. The forest fragment site (RI2), which had a relatively longer period of conservation, did have greater richness than reforested (GUA) or pasture (RI1) sites. Only the environment formerly used for crops (CXS) had lower richness compared to other sites. This generally agrees with the results from Lutinski and Garcia (2005) highlighting the importance of ants as environmental indicators, and the potential importance of ant conservation in the PPA.

Eight ant species were positively associated with sample sites. The Neotropical genera Camponotus, Pheidole and Solenopsis are highly diverse and can be locally abundant. Silvestre et al. (2003) characterize these genera as having generalist and aggressive behavior, and by strong association with disturbed environments. The positive association of $O$. chelifer and $P$. striata with GUA, CXS, and RI2 is also interesting because these are predators of other invertebrates. These results suggest that after five years of recovery, the PPA already houses a diversity of organisms capable of maintaining these ant species.

The results indicate that increased richness and abundance of vegetation since the formation of the HPP lake has promoted changes in habitat structure, and that these changes contribute to the maintenance of diversity in ant groups known to be ecologically important at various trophic levels. This trend was also observed in studies by Lassau et al. (2005), Lutinski et al. (2014), and Cantarelli et al. (2015).

This study provides new information concerning ant richness and abundance over the ecological recovery process in the PPA. It presents an inventory of species that are capable of colonizing environments with different land use histories that have been isolated and allowed to undergo natural regeneration processes. Considering the diversity of ant fauna and other associated organisms in the current study, we may consider this area a model for understanding recovery dynamics in HPP lake areas in southern Brazil. These results may also serve as the basis for monitoring of ecological and community regeneration in the HPP permanent protection area.

\section{ACKNOWLEDGMENTS}

The Foz do Chapecó consortium granted permission to sample in the PPA. This research was supported by a Conselho Nacional de Desenvolvimento Científico e Tecnológico (CNPq) Research Productivity Grant (Flávio Roberto Mello Garcia).

\section{REFERENCES}

ALONSO LE. 2000. Ants as Indicator of Diversity. In: Agosti D et al. (Eds), Ants: Standard methods for measuring and monitoring biodiversity, Washington D.C.: Smithsonian Institution Press, USA, p. 80-88.

ANEEL. 2016. BIG - Generation Information Bank. Electronic Database accessible at: http://www2.aneel.gov.br/ aplicacoes/capacidadebrasil/capacidadebrasil.cfm. Agência Nacional de Energia Elétrica - ANEEL, Distrito Federal.

ANDERSEN AN. 1997. Using Ants as Bioindicators: Multiscale Issue in Ant Community Ecology. Conserv Ecol 1: 1-8.

ANDERSEN AN AND MAJER JD. 2004. Ants show the way down under: invertebrates as bioindicators in land management. Fr Ecol Environ 2: 291-298.

ARMBRECHT I, PERFECTO I AND VANDERMEER J. 2004. Enigmatic biodiversity correlations: ant diversity responds to diverse resources. Science 304: 284-286.

BACCARO BB, FEITOSA RM, FERNANDEZ F, FERNANDES IO, IZZO TJ, SOUZA JLP AND SOLAR R. 2015. Guia para gêneros de formigas no Brasil, $1^{\mathrm{a}}$ ed., Manaus: INPA, 388 p.

BARBOSA FILHO WP. 2013. Impactos ambientais em usinas eólicas. Agrener GD 2013, Belo Horizonte: Fundação Estadual do Meio Ambiente, p. 1-17.

BENSUSAN N. 2006. Conservação da biodiversidade em áreas protegidas, Rio de Janeiro: FGV, 176 p.

BOLTON B. 2003. Synopsis and classification of Formicidae, Gainesville, USA: Memoirs of the American Entomological Institute, $370 \mathrm{p}$. 
BRAZIL. 2012. Forest Code. Law n ${ }^{\circ}$ 12,651 of May 25, 2012 , Brasília: Diário Oficial da União. Accessible at: http:// www.planalto.gov.br/ccivil_03/_ato2011-2014/2012/lei/ 112651.htm.

CANTARELLI EB, FLECK MD, GRANZOTTO F, CORASSA JN AND D'AVILA M. 2015. Diversidade de formigas (Hymenoptera: Formicidae) da serrapilheira em diferentes sistemas de uso do solo. Ciên Florestal 25(3): 607-616.

CHAO A. 1987. Estimating the population size for capturerecapture data with unequal catchability. Biometrics 43(4): 783-791.

CHAO A, COLWELL RK, LIN CW AND GOTELLI NJ. 2009. Sufficient sampling for asymptotic minimum species richness estimators. Ecol 90(4): 1125-1133.

COLWELL RK. 2006. EstimateS: Staistical Estimation of Species Richness and Share Species from Simples (Software and User's Guide). Version 8. Electronic Database accessible at: http://viceroy.eeb.ucon.edu/ estimates.

DELLA LUCIA TMC. 1993. As formigas cortadeiras. Viçosa: Editora Folha da Mata, 262 p.

DIAMOND J. 2012. Colapso, $8^{\mathrm{a}}$ ed., Rio de Janeiro: Editora Record, 699 p.

FERNÁNDEZ F. 2003. Introducción a lashormigas de la región neotropical. Bogotá, Colombia: Instituto de Investigación de Recursos Biológicos Alexander von Humboldt, 433 p.

FLECK MD, CANTARELLI EB AND GRANZOTTO F. 2015. Registro de novas espécies de formigas (Hymenoptera: Formicidae) no estado do Rio Grande do Sul. Ciên Florestal 25(2): 491-499.

FOWLER HGL, FORTI C, BRANDÃO CRF, DELABIE JHC AND VASCONCELOS HL. 1991. Ecologia Nutricional de formigas. In: Pazzini AR and Parra JRP (Eds), Ecologia nutricional de insetos e suas implicações no manejo de pragas. São Paulo: Manole, p. 131-209.

FOZ DO CHAPECÓ. 2015. Online information about the consortium of the Foz do Chapecó Hydroelectric Plant. Electronic Database accessible at: http:www.fozdochapeco. com.br. Consórcio Foz do Chapecó, Florianópolis, Santa Catarina.

GALINDO-LEAL C AND CÂMARA IG. 2003. The Atlantic Forest of South America. Biodiversity status, threats, and outlook. Washington DC: Island Press, 488 p.

GARDNER TA. 2010. Monitoring forest biodiversity: improving conservation through ecologically-responsible management. London: Earthscan, 360 p.

GIBSON L ET AL. 2011. Primary forests are irreplaceable for sustaining tropical biodiversity. Nature 478: 378-383.

GONÇALVES CR. 1961. O Gênero Acromyrmex no Brasil. Stud Entomol 4: 113-180.
GOTELLI NJ AND COLWELL RK. 2001. Quantifying biodiversity: procedures and pitfalls in the measurement and comparison of species richness. Ecol Lett 4: 379-391.

GOTELLI NJ AND ENTSMINGER GL. 2001. EcoSim: Null models software for ecology. Versão 7.0. Acquired Intelligence Inc. \& Kesey-Bear. Electronic Database accessible at: http:// homepages.together.net/ gentsmin/ ecosim.htm.

HAMMER O, HARPER DAT AND RIAN PD. 2001. Past: Palaeonthological statistics software package for education and data analysis. Version. 1.37. Electronic Database accessible at: http://palaeo-electronica.org/2001_1/past/ issue1_01.htm.

HÖLLDOBLER B AND WILSON EO. 1990. The Ants. Massachusetts, Cambridge: Harvard University Press, 732 p.

ILHA C, LUTINSKI JA, PEREIRA DVM AND GARCIA FRM. 2009. Riqueza de formigas (Hymenoptera: Formicidae) da Bacia da Sanga Caramuru, município de Chapecó-SC. Biotemas 22(4): 95-105.

INMET - INSTITUTO NACIONAL DE METEOROLOGIA. 2009. In: Ramos AM et al. (Org), Normais Climatológicas do Brasil 1961-1990: edição revisada e ampliada. Brasília: INMET, $465 \mathrm{p}$.

IOP S, CALDART VM, LUTINSKI JA AND GARCIA FRM. 2009. Formigas urbanas da cidade de Xanxerê, Santa Catarina, Brasil. Biotemas 22(2): 55-64.

KEMPF WW. 1964. A revision of the Neotropical fungusgrowing ants of the genus Cyphomyrmex Mayr. Part 1: Group of strigatus Mayr. Stud Entomol 7: 1-44.

KEMPF WW. 1965. A revision of the Neotropical fungusgrowing ants of the genus Cyphomyrmex Mayr. Part II: Group of rimosus (Spinola) (Hym., Formicidae). Stud Entomol 8: 161-200.

KING JR, ANDERSEN AN AND CUTTER AD. 1998. Ants as bioindicators of habitat disturbance: validation of the functional group model for Australia's humid tropics. BiodivConserv 7: 1627-1638.

KLIEMANN BCK AND DALARIVA RL. 2015. Pequenas centrais hidrelétricas: cenários e perspectivas no estado do Paraná. Ciênc e Nat 37(3): 274-283.

LASSAU SA, HOCHULI DF, CASSIS G AND REID CAM. 2005. Effects of habitat complexity on forest beetle diversity: do trophic groups respond consistently? Diversity and Distributions 11: 73-82.

LATTKE J. 1995. Revision of the ant genus Gnamptogenys in the New World (Hymenoptera: Formicidae). J Hymen Research 4: 137-193.

LATTKE JE. 2003. Subfamilia Ponerinae. In: Fernández F (Ed), Introducción a las hormigas de la región neotropical. Bogotá, Colômbia: Instituto de Investigación de Recursos Biológicos Alexander von Humboldt, p. 261-276. 
LOECK AE, GRUTZMACHER DD AND COIMBRA SM. 2003. Ocorrência de formigas cortadeiras do gênero Acromyrmex nas principais regiões agropecuárias do Rio Grande do Sul. Rev Bras Agrociência 9(2): 129-133.

LONGINO JT. 2003. The Crematogaster (Hymenoptera, Formicidae, Myrmicinae) of Costa Rica. Zootaxa 151: 1-150.

LONGINO JT AND FERNÁNDEZ F. 2007. Taxonomic review of the genus Wasmannia. In: Snelling RR et al. (Org), Advances in ant systematics (Hymenoptera: Formicidae): homage to E.O. Wilson - 50 years of contributions. Memoirs of the American Entomological Institute, p. 271-289.

LUTINSKI JA, BAUCKE L, FILTRO M, BUSATO MA, KNAKIEWICZ AC AND GARCIA FRM. 2016. Ant assemblage (Hymenoptera: Formicidae) in three wind farms in the State of Paraná, Brazil. Braz J Biol 4: 1-9.

LUTINSKI JA AND GARCIA FRM. 2005. Análise faunística de Formicidae (Hymenoptera: Apocrita) em ecossistema degradado no município de Chapecó, Santa Catarina. Biotemas 18(2): 73-86.

LUTINSKI JA, GARCIA FRM, LUTINSKI CJ AND IOP S. 2008. Diversidade de formigas na Floresta Nacional de Chapecó, Santa Catarina, Brasil. Ciênc Rural 38(7): 18101816.

LUTINSKI JA, LOPES BC AND MORAIS ABB. 2013. Diversidade de formigas urbanas (Hymenoptera: Formicidae) de dez cidades do sul do Brasil. Biota Neotrop 13(3): 333-342.

LUTINSKI JA, LUTINSKI CJ, LOPES BC AND MORAIS ABB. 2014. Estrutura da comunidade de formigas (Hymenoptera: Formicidae) em quatro ambientes com diferentes níveis de perturbação antrópica. Ecol Austral 24: 229-237.

MACIEL L, IANTAS J, GRUCHOWSKI-W FC AND HOLDEFER DR. 2011. Inventário da fauna de formigas (Hymenoptera: Formicidae) em ambiente de sucessão ecológica florística no município de União da Vitória, Paraná. Biodiv Pampeana 9(1): 38:43.

MADEIRA BG, ESPÍRITO-SANTO MM, D'ÂNGELONETO S, NUNES YRF, SÁNCHEZ-AZOFEIFA GA, FERNANDES GW AND QUESADA M. 2009. Changes in tree and Liana communities along a successional gradient in a tropical dry forest in south-eastern Brazil. Plant Ecology 201: 291-304.

MAJER JD. 1983. Ants: bioindicators of Minesite Rehabilitation, land use, and land conservation. Env Managment 7: 375-383.

MAKAY WP, LÓPEZ-CASTRO C AND FERNÁNDEZ F. 2002. A new, high altitude Colombian species of the ant genus Camponotus with dimorphic males and females. Sociobiol 40: 421-430.
MARQUES AC AND LAMAS CJE. 2006. Taxonomia zoológica no Brasil: estado da arte, expectativas e sugestões de ações futuras. Pap Avulsos Zool 46(13): 139-174.

MELO AS, PEREIRA RAS, SANTOS AJ, SHEPHERD GJ, MACHADO G, MEDEIROS HF AND SAWAYA RJ. 2003. Comparing species richness among assemblages using sample units: why not use extrapolation methods to standardize different sample sizes? Oikos 101(2): 398-410.

NAYANA P, PRESTY J, BAABY J AND LAKSHMI PDM. 2016. Comparison of Ant (Hymenoptera: Formicidae) Diversity in Different Habitats of Machad Region of Thrissur. Bull Env Pharmacol Life Sci 5(2): 28-33.

NEVES FS, BRAGA RF, ESPÍRITO-SANTO MM, DELABIE JHC, FERNANDES GW AND SANCHEZ-AZOFEIFA GA. 2010. Diversity of arboreal ants an a Brazilian Tropical Dry Forest: Efects of seasonality and successional Stage. Sociobiol 56: 177-194.

OLIVEIRA MF AND CAMPOS-FARINHA AEC. 2005. Formigas urbanas do município de Maringá, PR, e suas implicações. Arq do Inst Biol 72(1): 33-39.

PEREIRA MP, QUEIROZ J, VALCARCEL R AND MAYHÉNUNES AJ. 2007. Fauna de formigas como ferramenta para monitoramento de área de mineração reabilitada na Ilha da Madeira, Itaguaí, RJ. Ciênc Florestal 17: 197-204.

PERFECTO I AND VANDERMEER J. 2002. Quality of agroecological matrix in a tropical montane landscape: ants in coffee plantations in southern Mexico. Conserv Biol 16: 174-182.

PETTERS MK, LUNG T, SCHAAB G AND WÄGELE JW. 2011. Deforestation and the population decline of the army ant Dorylus wilverthi in western Kenya over the last century. J Appl Ecol 48: 697-705.

RIBAS CR, SCHMIDT FA, SOLAR RRC, CAMPOS RBF, VALENTIM CL AND SCHOEREDER J H. 2012. Ants as indicators of the success of rehabilitation efforts in deposits of gold mining tailings. Rest Ecol 20(6): 712-720.

ROMERO H AND JAFFE K. 1989. A comparison of methods for sampling ants (Hymenoptera: Formicidae) in Savanna. Biotropica 21: 348-352.

SILVA RR AND BRANDÃO CRF. 1999. Formigas (Hymenoptera: Formicidae) como indicadores da qualidade ambiental e da biodiversidade de outros invertebrados terrestres. Biotemas 12(2): 55-73.

SILVA RR AND SILVESTRE R. 2004. Diversidade de formigas (Hymenoptera: Formicidae) que habita as camadas superficiais do solo em Seara, Oeste de Santa Catarina. Pap Av de Zool 44: 1-11.

SILVESTRE R, BRANDÃO CRF AND SILVA RR. 2003. Grupos funcionales de hormigas: el caso de los grêmios del cerrado. In: Fernández F (Ed), Introducción a las hormigas de la región neotropical. Bogotá, Colombia: Instituto de Investigación de Recursos Biológicos Alexander von Humboldt, p. 113-148. 
TABER SW. 1998. The world of the harvester ants. College Station: Texas A \& M University Press, 213 p.

TUNDISI JG AND TUNDISI TM. 2010. Impactos potenciais das alterações do Código Florestal nos recursos hídricos. Biota Neotrop 10(4): 67-76.

ULYSHEN MD. 2011. Arthropod vertical stratification in temperate deciduous forests: Implications for conservationoriented management. Forest Ecol and Manag 261: 14791489.

ULYSSÉA MA, CERETO CE, ROSUMEK FB, SILVA RR AND LOPES BC. 2011. Updated list of ant species (Hymenoptera, Formicidae) recorded in Santa Catarina State, southern Brazil, with a discussion of research advances and priorities. Rev Bras de Entomol 55(4): 603611.

WATKINS JF. 1976. The identification and distribution of New World army ants (Dorylinae: Formicidae). Waco: Markham Press Fund of Baylor University Press, 102 p.
WETTERER JK. 2012. Worldwide spread of Emery's sneaking ant, Cardiocondyla emeryi (Hymenoptera: Formididae). Myrm News 17: 13-20.

WILD AL. 2007. Taxonomic revision of the ant genus Linepithema (Hymenoptera: Formicidae). Univ Calif Publ Entomol 126: 1-159.

WILSON EO. 2003. Pheidole in the new world. Harvard University Press, 776 p.

\section{SUPPLEMENTARY MATERIAL}

Table SI - Relative abundance of ant species per sample site at the Permanent Preservation Area of the Foz do Chapecó Hydroelectric Power Plant lake in the Guatambu (GUA) and Caxambu do Sul (CXS) municipalities in Santa Catarina, and the Rio dos Índios (RI1 and RI2) municipality in Rio Grande do Sul. 